\title{
Literature Review : Gambaran Status Gizi Pada Anak Usia 0 Sampai 5 Tahun Di Masa Pandemi Covid-19
}

\author{
Lusi Meikasari $^{{ }^{*}}{ }$, Neti Mustikawati ${ }^{2}$ \\ 1,2 Program Studi Sarjana Keperawatan, Universitas Muhammadiyah Pekajangan Pekalongan, \\ Indonesia \\ *email: 1
}

\begin{abstract}
Poor nutritional status has an impact on the body of toddlers, namely toddlers will experience failure to grow. Thear bodies will become short. They may also experience malnutrition if they do not get the right nutritional intak, especially during this Covid-19 pandemic. Therefore, to prevent nutritional problems, it is very necessary to monitor their nutritional status. To analyze the nutritional status of children aged 0 to 5 years old during the Covid-19 pandemic. The method used in this research is a literature review. The selected articles where published in 2019-2021from the science direct database (1 article) and Google Scholer (4 article). The results were obtained according to the keywords and inclusion criteria. Then, they were analyzed using the JBI instrument. The result were concluded by using BMI and BB/U measurement tools. Characteristics of children were fount in 3 articles. It was the age period of aged 0 to 3 years. the gender characteristics of children were found in 3 article. It was male. The nutritional status of children aged 0 to 5 years are mostly good/normal nutritional status with a total of 358 children. Based on the overview of nutritional status in children aged 0 to 5 years during the Covid-19 pandemic, most of the nutritional status is good / normal.
\end{abstract}

Keywords: Nutritional status; Children aged 0 to 5 years; Covid-19 pandemic;

\begin{abstract}
Abstrak
Keadaan status gizi yang tidak baik memiliki dampak terhadap tubuh balita yaitu balita akan mengalami kegagalan dalam tumbuh, tubuh akan menjadi pendek dan mengalami malnutrisi apabila tidak mendapatkan asupan nutrisi yang benar. Terutama pada masa pandemi Covid19 ini, agar anak tidak mengalami masalah gizi maka sangat diperlukan pemantauan status gizinya. Untuk melakukan analisis pada Status Gizi pada anak usia 0 sampai 5 tahun pada masa pandemi Covid-19. Metode yang digunakan dalam penelitian ini adalah literature review, pencarian artikel pada rentang waktu 3 tahun yaitu 2019-2021 melalui penelusuran database science direct 1 artikel dan google scholar 4 artikel. Hasil pencarian didapatkan sesuai kata kunci dan kriteria inklusi, dianalisa menggunakan instrument JBI. Dengan menggunakan alat ukur IMT dan BB/U lalu disimpulkan. Karakteristik anak terdapat 3 artikel yaitu berusia 0 sampai 3 tahun, karakteristik jenis kelamin anak terdapat dari 3 artikel yaitu laki-laki, status gizi anak usia 0 sampai 5 tahun mayoritas berstatus gizi baik/normal dengan jumlah sebanyak 358 anak. Gambaran terhadap status gizi pada anak usia 0 Sampai 5 Tahun di masa pandemi Covid-19 mayoritas status gizi memiliki status gizi baik / normal
\end{abstract}

Kata kunci: Status Gizi; Anak usia 0 Sampai 5 Tahun; Pandemi Covid-19;

\section{Pendahuluan}

Masa bayi dimulai dari periode 0 hari atau hari setelah lahir hingga usia 2 tahun, periode ini merupakan periode kritis pada masa pertumbuhan atau disebut Golden Periode. Masa bayi memiliki perkembangan fisik, kecerdasan, emosi, bahasa dan kepribadian. WHO menyatakan bahwa anak dibawah 5 tahun (Balita) yang dibagi 


\section{Prosiding Seminar Nasional Kesehatan Lembaga Penelitian dan Pengabdian Masyarakat Universitas Muhammadiyah Pekajangan Pekalongan}

menjadi 3 golongan yaitu usia bayi 0 sampai 1 tahun, batita 2-3 tahun, dan golongan prasekolah 4-5 tahun. Usia balita dan prasekolah yang pertumbuhannya tidak sepesat masa pertumbuhan bayi, tetapi aktivitas pada masa ini lebih tinggi dibandingkan masa bayi [7].

Balita adalah anak usia yang kurang dari lima tahun, balita dapat dikatakan merupakan usia yang memasuki masa pensapihan atau berhenti menyusui sampai usia prasekolah. Balita usia 1 sampai 5 tahun dibedakan menjadi dua, yaitu usia anak satu tahun sampai tiga tahun dikenal dengan sebutan Batita dan usia anak tiga tahun sampai usia lima tahun disebut prasekolah. Karakteristik balita merupakan konsumen pasif, kebutuhan jumlah makanan cukup besar namun dengan ukuran perut yang kecil balita jumlah asupan yang diberikan juga dalam porsi kecil sehingga pemberian asupan diberikan adalah porsi dengan frekuensi sering. Balita atau anak bawah lima tahun merupakan kelompok yang sering menderita kekurangan gizi dan tidak jarang yang mengalami keterlambatan pertumbuhan dengan salah satu penyebab utama yaitu gizi yang tidak terpenuhi. Oleh karena itu, penting dalam pemberian makanan pada anak, peran orang tua dibutuhkan sebagai penyedia dan pendamping dalam memenuhi kebutuhan gizi yang dapat mempengaruhi tumbuh kembangnya [13].

Kebutuhan gizi pada anak memerlukan asupan gizi yang harus terpenuhi untuk menunjang kesehatan, kebutuhan gizi yang dibutuhkan pada setiap anak beragam sama dengan kebutuhan kandungan zat gizi yang diperlukan. Kebutuhan gizi yang berasal dari makanan yang dikonsumsi sehari-hari, seperti; karbohidrat, lemak, protein, zat besi, vitamin dan juga mineral sangat diperlukan dalam memenuhi kebutuhan dalam kehidupan. Hal tersebut dapat menentukan status gizi pada balita dimana kondisi balita lebih rentan terkena dampak yang cukup besar bila tidak terpenuhi kebutuhan gizi. Kekurangan asupan nutrisi dalam kehidupan sehari-hari dapat menetukan keadaan status gizi yang berpengaruh secara tidak langsung pada pada kesehatan[6].

Status gizi pada balita merupakan hal yang perlu mendapatkan perhatian serius, jika terdapat kekurangan gizi pada masa ini dapat menyebabkan kerusakan yang ireversible atau tidak dapat dipulihkan. Tubuh yang pendek merupakan salah satu tanda kurang gizi pada balita, kekurangan gizi pada balita yang lebih fatal dapat berakibat pada perkembangan otaknya. Status gizi dapat dilihat dari mencocokan dengan umur anak dan berat badanya sedangkan status gizi pada orang dewasa dilihat mengunakan IMT atau indeks masa tubuh. Penyebab kurang gizi pada balita adalah kemiskinan, diare, kurang pengetahuan orang tua, ataupun dalam faktor tabu makanan atau makanan bergizi yang tidak dapat dikonsumsi oleh [13]

Menurut Kementrian Kesehatan Republik Indonesia (kemenkes RI) berdasarkan dari hasil Riset Kesehatan Dasar, kondisi anak menunjukan hasil perbaikan. Terkait masalah stunting terjadi penurunan yang prevelensi pada anak balita dari 37,21\% pada tahun 2013 menjadi 30,79\% ditahun 2018. Bila dibandingkan dengan data prevalensi pada anak balita tahun 2016 (Sirkesnas) ,yaitu 33,60\%. Selain dari itu perbaikan gizi bisa tercermin dari penurunanya kekurangan gizi (underweight) pada anak balita yang dari $19,6 \%$ pada saat tahun 2013 menjadi $17,68 \%$ pada tahun 2018 . Penurunan kekurangan gizi atau anak balita kurus dari 12,12\% pada tahun 2013 


\section{Prosiding Seminar Nasional Kesehatan Lembaga Penelitian dan Pengabdian Masyarakat Universitas Muhammadiyah Pekajangan Pekalongan}

menjadi $10,19 \%$ tahun 2018 . Terkait dengan kegemukan (obesitas) pada anak balita juga mengalami perbaikan dengan penurunan dari 11,90\% pada tahun 2013 menjadi 8,04\% tahun 2018. Kementri Kesehatan RI mengatakan dalam upaya perbaikan gizi harus didukung dari pemerintah sampai masyarakat untuk menekan angka stunting dan berbagai penyakit pada anak balita (Kementrian kesehatan Republik Indonesia, 2019).

Keadaan status gizi yang tidak baik memiliki dampak terhadap tubuh balita yaitu balita akan mengalami kegagalan dalam tumbuh, tubuh akan menjadi pendek dan mengalami malnutrisi apabila tidak mendapatkan asupan nutrisi yang benar dengan keadaan gizi yang telah di bedakan diantaranya; gizi buruk, gizi kurang, gizi baik dan gizi lebih. Di masa pandemi Covid-19 ini anak akan mengalami krisis gizi, di mana pandemi berdampak berat dalam keamanan pangan rumah tangga dan kesulitan mencari bahan makanan yang sehat. Penyebaran Covid-19 dapat mempengaruhi prekonomian keluarga sehingga uang untuk mencukupi kebutuhan gizi menjadi kurang, ketidakamanan pangan rumah tangga meningkatkan prevelensi kurang gizi. Sehingga dampak panjang Covid-19 dapat meningkatkan jumlah balita stunting (Unicef, 2020).

Indonesia melakukan bermacam upaya untuk mengendalikan pandemi tersebut yang menimbulkan dampak pada usia dini seperti bayi dan balita, meski resiko infeksi lebih rendah dibanding usia dewasa. Sekitar 80 juta anak Indonesia atau 30\% dari seluruh populasinya dengan potensi mengalami dampak serius disebabkan dampak sekunder baik jangka pendek maupun jangka panjang terhadap kesehatan, kesajaterahan, perkembangan dan masa depan anak. Covid-19 memberikan dampak merugikan dalam sektor ekonomi mengalami penurunan perkonomian rata-rata 3-4\% pada tahun 2020, sehingga dapat menimbulkan kesulitan dalam perekonomian yang dapat berujung pada kemiskinan. krisis gizi memberikan dampak dimana kebutuhan makan akan sulit didapatkan sehingga anak akan mengalami kekurangan gizi dan menjadikan anak semakin kurus sehingga mengalami malnutrisi (Unicef,2020). Berdasarkan Latar Belakang penelitian maka dapat dirumuskan pertanyaan sebagai berikut "Bagaimana Gambaran Status Gizi pada Anak usia 0 sampai 5 tahun dimasa pandemi Covid-19 ?"

\section{Literature Review}

Literatur review berisi diskusi pengetahuan tentang topik yang sedang dipelajari untuk memperkuat gagasan riset.

\section{Metode}

Metode penelitian ini merupakan berjenis literature review, pencarian artikel pada rentang waktu 3 tahun yaitu 2019-2021, dalam pencarian database online Google Scholar (https://scholar.google.com/) didapatkan 1 Artikel dalam pencarian jurnal bahasa Indonesia dan Science Derict dalam pencarian jurnal internasional (https://www.sciencedirect.com) didapatkan 4 Artikel. Hasil pencarian kemudian disesuaikan dengan kriteria eksklusi, dan penecarian dihentikan apabila sudah menemukan minimal 5 artikel yang sesuai dengan peneliti, dianalisa menggunakan instrument JBI (Joanna Briggs Institute) merupakan instrument merupakan penilaian 


\section{Prosiding Seminar Nasional Kesehatan Lembaga Penelitian dan Pengabdian Masyarakat Universitas Muhammadiyah Pekajangan Pekalongan

kualitas metodologi sebuah studi dan untuk menentukan sejauh mana sebuah studi telah menangani kemungkinan bias dalam disain, prilaku dan analisisnya.

\section{Hasil dan Pembahasan}

\section{Hasil}

Hasil analisis data atau literature review berdasarkan variable penelitian yaitu status gizi anak pada masa pandemi Covid-19 dengan mengunakan dua alat ukur yaitu IMT \& BB/U sebagai berikut :

Tabel 4.1 Distribusi Frekuensi Berdasarkan Karakteristik Usia Anak

\begin{tabular}{|c|c|c|c|c|c|c|}
\hline \multirow{3}{*}{ No } & \multicolumn{2}{|l|}{ Artikel } & \multicolumn{4}{|c|}{ Karakteristik Usia } \\
\hline & \multirow{2}{*}{ Penulis } & \multirow{2}{*}{ Tahun } & \multicolumn{2}{|r|}{$0-3$} & \multicolumn{2}{|r|}{ 4-5 } \\
\hline & & & $\mathrm{F}$ & $\%$ & $\mathrm{~F}$ & $\%$ \\
\hline 1 & Amirullah,et.al & 2020 & 2 & $(7,4 \%)$ & 25 & $(92,6 \%)$ \\
\hline 2 & Sari,et.al & 2020 & 75 & $(100 \%)$ & 0 & 0 \\
\hline 3 & Indrayan, et.al & 2020 & NM & NM & NM & NM \\
\hline 4 & Setyorini \& Lieskusumastuti & 2021 & 72 & $(53,3 \%)$ & 63 & $(46,7 \%)$ \\
\hline 5 & Candriasih,et.al & 2021 & NM & NM & NM & NM \\
\hline \multicolumn{3}{|c|}{ Total masing-masing karakteristik usia responden } & 149 & $(62,87 \%)$ & 88 & $(54,32 \%)$ \\
\hline \multicolumn{3}{|c|}{ Total karakteristik usia } & \multicolumn{4}{|c|}{237} \\
\hline
\end{tabular}

Berdasarkan artikel yang dilakukan review, yang membahas karakeristik berdasarkan usia anak diperoleh hasil analisis literature review. Dari (Tabel 4.1) dari 5 artikel diperoleh dari 3 artikel yang terdapat usia anak 0 sampai 3 tahun dari artikel [1] sebanyak $2(7,4 \%)$ anak, [17] sebanyak 75 (100\%) anak dan [18] sebanyak 72 $(53,3 \%)$ anak dan ditotal sebanyak $149(62,87 \%)$ anak. Kemudian anak usia 4 sampai 5 tahun dari artikel [1] sebanyak $25(92,6 \%)$ anak, [18] sebanyak $63(46,7 \%)$ anak dan ditotal sebanyak 88 (54,35\%) anak dengan keseluruhan total usia anak 0 sampai 5 tahun sebanyak 237 anak. Dan disimpulkan karakteristik berdasarkan usia yang paling banyak dari 3 artikel yaitu rentang usia 0 sampai 3 tahun.

Tabel 4.2 Distribusi Frekuensi Berdasarkan Karakteristik Jenis Kelamin Anak

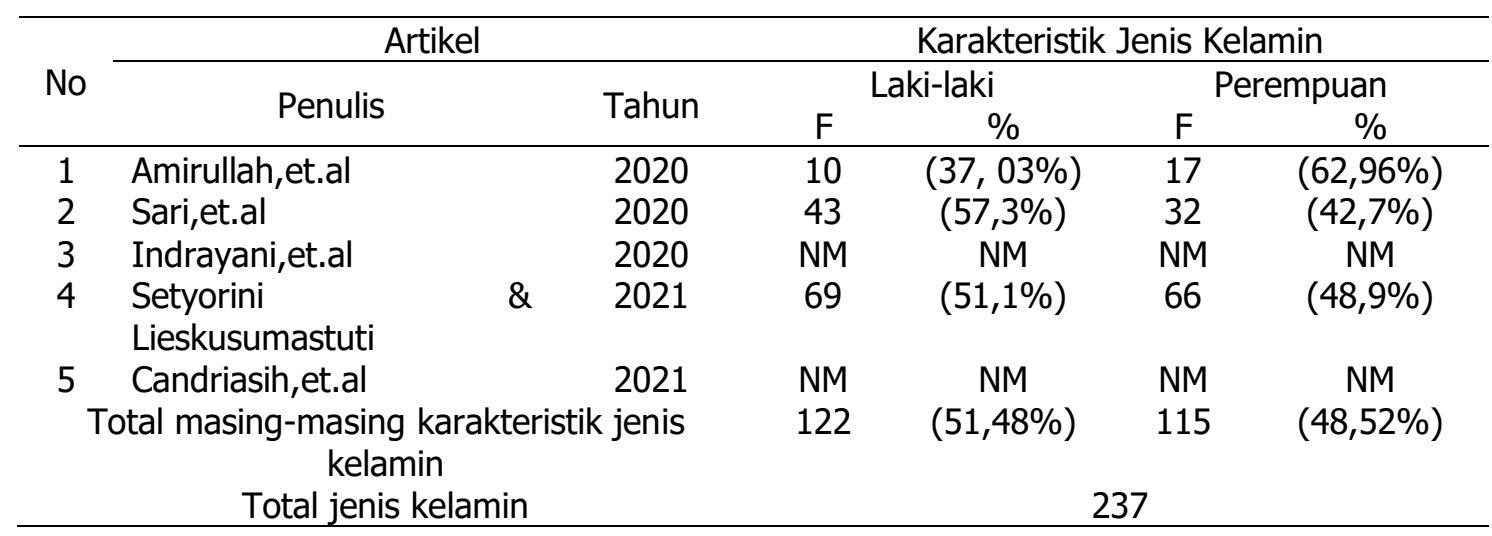

Berdasarkan artikel yang dilakukan review, yang membahas karakeristik berdasarkan jenis kelamin Anak diperoleh hasil analisis literature review. Dari (Tabel 4.2) dari 5 artikel didapatkan 3 artikel yang terdapat anak dengan jenis kelamin lakilaki dari artikel [1] sebanyak 10 (37,03\%) anak, [17] sebanyak 43 (57,3\%) anak, dan (Setyorini \& Lieskusumastuti, 2021) sebanyak 69 (51,1\%) anak dengan total sebanyak 


\section{Prosiding Seminar Nasional Kesehatan Lembaga Penelitian dan Pengabdian Masyarakat Universitas Muhammadiyah Pekajangan Pekalongan

122 (50,32\%) anak. Kemudian jenis kelamin perempuan dari artikel sebanyak (Amirullah et al., 2020) sebanyak 17 (62,96\%) anak, [17] sebanyak 32 (42,7\%) anak, dan [18] sebanyak $66(48,9 \%)$ anak dengan total sebanyak 115 (48,52\%) anak. Dan disimpulkan bahwa balita berjenis kelamin laki-laki lebih banyak dari pada perempuan.

Tabel 4.3 Distribusi Frekuensi Status Gizi Berdasarkan IMT

\begin{tabular}{|c|c|c|c|c|c|c|c|c|c|c|}
\hline \multirow{3}{*}{ NO } & \multicolumn{2}{|c|}{ Artikel } & \multicolumn{8}{|c|}{ Tingkat Status gizi balita } \\
\hline & \multirow{2}{*}{ Penulis } & \multirow{2}{*}{ Tahun } & \multicolumn{2}{|c|}{$\begin{array}{c}\text { Sangat } \\
\text { kurus }\end{array}$} & \multicolumn{2}{|c|}{ Kurus } & \multicolumn{2}{|c|}{ Normal } & \multicolumn{2}{|c|}{ Gemuk } \\
\hline & & & $\mathrm{F}$ & $\%$ & $\mathrm{~F}$ & $\%$ & $\mathrm{~F}$ & $\%$ & $\mathrm{~F}$ & $\%$ \\
\hline 1 & Amirullah,et.al & 2020 & 0 & 0 & 4 & $\begin{array}{c}14,8 \\
\%\end{array}$ & 22 & $\begin{array}{c}81,5 \\
\%\end{array}$ & 1 & $3,7 \%$ \\
\hline 2 & Candriasih,et.al & 2021 & 2 & $5,7 \%$ & 20 & $\begin{array}{c}57,1 \\
\%\end{array}$ & 13 & $\begin{array}{c}37,1 \\
\%\end{array}$ & 0 & 0 \\
\hline \multicolumn{3}{|c|}{ Total masing-masing status gizi } & 2 & $\begin{array}{c}3,85 \\
\%\end{array}$ & 24 & $\begin{array}{c}46,1 \\
5 \%\end{array}$ & 25 & $\begin{array}{c}48 \\
08 \%\end{array}$ & 1 & $\begin{array}{c}1,92 \\
\%\end{array}$ \\
\hline & Total status & & \multicolumn{8}{|c|}{52} \\
\hline
\end{tabular}

Tabel 4.4 Distribusi Frekuensi Status Gizi Berdasarkan BB/U

\begin{tabular}{|c|c|c|c|c|c|c|c|c|}
\hline \multirow{3}{*}{ NO } & \multicolumn{2}{|c|}{ Artikel } & \multicolumn{6}{|c|}{ Tingkat Status gizi balita } \\
\hline & \multirow{2}{*}{ Penulis } & \multirow[b]{2}{*}{ Tahun } & \multicolumn{2}{|c|}{ Kurang } & \multicolumn{2}{|c|}{ Baik } & \multicolumn{2}{|c|}{ Lebih } \\
\hline & & & $\mathrm{F}$ & $\%$ & $\mathrm{~F}$ & $\%$ & $\mathrm{~F}$ & $\%$ \\
\hline 1 & Sarii,et.al & 2020 & 9 & $12 \%$ & 56 & $74,7 \%$ & 10 & $13,3 \%$ \\
\hline 2 & Indrayani,et.al & 2020 & 16 & $16,7 \%$ & 80 & $\begin{array}{c}83,3 \% \\
0\end{array}$ & 0 & 0 \\
\hline 3 & $\begin{array}{l}\text { Setyorini \& } \\
\text { Lieskusumastuti }\end{array}$ & 2021 & 3 & $2,2 \%$ & 126 & $93,3 \%$ & 6 & $4,5 \%$ \\
\hline \multicolumn{3}{|c|}{ Total masing-masing status gizi } & 28 & $9,15 \%$ & 262 & $\begin{array}{c}85,62 \\
\% \\
\end{array}$ & 16 & $5,23 \%$ \\
\hline & Total status & & \multicolumn{6}{|c|}{306} \\
\hline
\end{tabular}

Berdasarkan artikel yang dilakukan review, yang membahas status gizi pada anak diperoleh hasil analisis literature review. Dari (Tabel 4.3) dengan mengunakan alat ukur IMT (Indeks Masa Tubuh) terdapat anak dengan status gizi sangat kurus 2 (3,85\%) anak, status gizi kurus 24 (46,15\%) anak, status gizi normal $25(48,08 \%)$ anak dan status gizi gemuk $1(1,92 \%)$ anak. Sedangkan pada Dari (Tabel 4.4) dengan mengunakan alat ukur BB/U terdapat anak dengan status gizi kurang $28(9,15 \%)$ anak, status gizi baik 262 (85,62\%) anak, dan status gizi lebih 16 (5,23\%) anak. Berdasarkan nilai status gizi paling banyak sehingga dapat disimpulkan dari kedua alat ukur status gizi dengan gizi normal / baik pada anak berada pada urutan pertama paling banyak.

\section{Pembahasan}

1. Karakteristik responden Anak Usia 0 Sampai 5 Tahun pada masa Pandemi Covid-19. Berdasarkan analisa yang telah dilakukan ke 5 artikel terdapat 3 artikel menghasilkan data frekuensi dan presentasi dari karakteristik responden, karakteristik responden yang ditemukan dan dibahas antara lain yaitu usia anak dan jenis kelamin anak. 


\section{Prosiding Seminar Nasional Kesehatan 2021 Lembaga Penelitian dan Pengabdian Masyarakat Universitas Muhammadiyah Pekajangan Pekalongan}

\section{a. Berdasarkan Usia}

Bayi dan balita adalah anak yang usianya dibawah 5 tahun, pada usia 0-5 tahun merupakan masa Golden Age pada masa balita [18]. Masa pertumbuhan balita usia 1 sampai 3 tahun merupakan usia masa pertumbuhan lebih cepat dibandingkan usia 4 sampai 5 tahun. Karakteristik balita merupakan konsumen pasif, kebutuhan jumlah makanan cukup besar namun dengan ukuran perut yang kecil jumlah asupan yang diberikan juga dalam porsi kecil sehingga pemberian asupan diberikan adalah porsi dengan frekuensi sering. Balita atau anak bawah lima tahun merupakan kelompok yang sering menderita kekurangan gizi dan tidak jarang yang mengalami keterlambatan pertumbuhan dengan salah satu penyebab utama yaitu gizi yang tidak terpenuhi . [13].

Berdasarkan karakteristik usia diketahui bahwa responden memiliki rentan usia 0 sampai 5 tahun, dari 3 artikel yaitu usia 0 sampai 3 tahun sebanyak $149(62,87 \%)$ anak merupakan rentan responden terbanyak, sedangkan usia 4 sampai 5 tahun sebanyak $88(37,18 \%)$ anak. Hal ini sejalan dengan penelitian [23] presentase anak dengan rentan usia 0 sampai 3 tahun sebanyak 19 (67\%) anak.

\section{b. Jenis kelamin}

Berdasarkan karakteristik jenis kelamin anak. Jumlah anak berjenis kelamin laki-laki sebanyak $122(51,48 \%)$ sedangkan yang berjenis kelamin perempuan sebanyak 115 (48,52\%), maka disimpulkan bahwa anak berjenis kelamin lakilaki lebih banyak dari pada perempuan. Hal ini sejalan dengan penelitian [4] presentase jumlah responden berjenis kelamin laki-laki 75 (52,1\%) sedangkan responden berjenis kelamin perempuan 69 (47,9\%).

2. Status Gizi Anak Usia 0 sampai 5 tahun dimasa Pandemi Covid-19

Status gizi adalah suatu kedaan gizi di mana keseimbangan zat gizi dalam bentuk yang variable tertentu atau perwujutan dari keadaan gizi. Status gizi sangat berpengaruh terhadap pertumbuhan dan perkembangan balita, balita dengan gizi kurang atau buruk akan memiliki tingkat kecerdasan yang lebih rendah. [21] menyatakan bahwa status gizi dapat dipengaruhi oleh berbagai faktor diantarnya dari faktor ekonomi, pengetahuan,budaya, produk pangan yang tidak mencukupi kebutuhan, kondisi fisik, lingkungan social, lingkungan politik, aktivitas fisik, dan pemilihan makanan.

Dampak jangka panjang bagi gizi buruk dapat terjadinya apatis, mengalami gangguan bicara dan berkembang dan sedangkan untuk dampak jangka panjang dapat menyebabkan penurunan skor IQ [18].

Kementran Kesehatan Republik Indonesia, 2019 menyatakan bahwa di katakan status gizi Kurus yaitu apabila nilai IMT menunjukkan angka $>17,0-18,4$ kemudian yang di katakana status gizi Normal yaitu apa bila nilai IMT menunjukan angka 18,5 - 25,0 dan yang di katakan status gizi Gemuk yaitu apa bila nilai IMT menunjukan angka 25,1 - >27,0. Status gizi normal yaitu suatu keadaan di mana tubuh dapat mencerminkan keseimbagan yang didapati dari konsumsi pangan dan pengunaan gizi dari tubuh. 


\section{Prosiding Seminar Nasional Kesehatan 2021 \\ Lembaga Penelitian dan Pengabdian Masyarakat Universitas Muhammadiyah Pekajangan Pekalongan}

Upaya penerapan gizi seimbang setiap keluarga harus mampu mengenal, mencegah, dan mengatasi masalah gizi setiap anggota keluarganya. Hal ini sesuai dengan Peraturan Menteri Kesegatan Nomor 23 Tahun 2014 tentang upaya perbaikan gizi. Dalam mencegah terjadinya gizi buruk juga dapat melakukan seperti menimbang BB secara teratur, memberikan ASI eksklusif, menu makan yang seimbang, dan memberikan suplemen gizi sesuai anjuran petugas kesehatan [18].

Berdasarkan analisis yang telah dilakukan ke-5 artikel menghasilkan data frekuensi dan presentasi mengenai status gizi pada balita usia 1 sampai 5 tahun yang telah dibedakan menjadi 4 kategori yaitu setatus gizi buruk, kurang, baik dan lebih. Alat ukur yang digunakan untuk mengukur status gizi yaitu IMT yang menunjukan sebagian besar status gizi balita dalam keadaan gizi normal sebanyak $25(48,08 \%)$ balita dan gizi baik sebanyak $262(85,62 \%)$.sedangkan yang menggunakan alat ukur BB/U menunjukan nilai status gizi baik sebanyak 262 (85,62\%). Hal ini sejalan dengan penelitian Apriliawati,et.al (2020) presentase jumlah responden dengan status gizi baik $92(63,9 \%)$ dan sejalan dengan penelitian Widiastuti,et al (2021) dengan hasil penelitian status gizi balita menunjukkan nilai normal sebnyak $102(81,6 \%)$.

Dilihat dari 5 artikel terdapat 2 artikel dengan alat ukur IMT menyatakan bahwa status gizi dalam keadaan gizi normal, dan 3 jurnal dengan alat ukur BB/U menyatakan bahwa status gizi dalam gizi baik. Sehingga dapat ditarik kesimpulan gambaran status gizi pada masa pandemi Covid-19 sebagian besar artikel telaah menyatakan dengan status gizi baik/normal.

\section{Kesimpulan}

Berdasarkan dari hasil dan pembahasan yang dipaparkan, maka dapat disimpulkan bahwa :

1. Karakteristik anak pada masa pandemi Covid-19, usia anak terbanyak yaitu usia 0 sampai 3 tahun sebanyak 149 (62,87\%) anak dan jenis kelamin pada anak terbanyak yaitu laki-laki sebanyak $122(51,48 \%)$ anak.

2. Status gizi anak pada masa pandemi Covid-19, terbagi menjadi dua pengukuran yaitu IMT dengan status gizi normal sebanyak 25 (48,08\%) anak dan BB/U dengan status gizi baik 264 (85,62\%) anak, sehingga disimpulkan bahwa keduanya sama-sama menunjukan jumlah anak terhadap status gizi pada keadaan baik atau normal.

\section{Referensi}

[1] Amirullah, A., Putra, A. T. A., \& Al Kahar, A. A. D. (2020). Deskripsi Status Gizi Anak Usia 3 Sampai 5 Tahun Pada Masa Covid-19. Murhum: Jurnal Pendidikan Anak Usia Dini, 16-27.

[2] Afrinis, N., Verawati, B., \& Hendarini, A. T. (2021). Analisis Faktor yang Berhubungan Dengan Status Gizi Bayi Usia 6-12 Bulan pada Masa Pandemi Covid-19. Prepotif: Jurnal Kesehatan Masyarakat, 5(1), 304-310. 


\section{Prosiding Seminar Nasional Kesehatan Lembaga Penelitian dan Pengabdian Masyarakat Universitas Muhammadiyah Pekajangan Pekalongan}

[3] Akbar, D. M., \& Aidha, Z. (2020). Perilaku Penerapan Gizi Seimbang Masyarakat Kota Binjai Pada Masa Pandemi Covid-19 Tahun 2020. Menara Medika, 3(1).

[4] Apriliawati, A., Purwati, N. H., Sutini, T., Awaliah, A., Astuti, M. A., Adharani, Y., ... \& Safitri, Y. (2021, February). Edukasi dan Skrining Gizi Balita Berbasis Aplikasi STRONGKids. In Prosiding Seminar Nasional Pengabdian Masyarakat LPPM UMJ (Vol. 1, No. 1).

[5] Chomariah, N. (2015). Panduan Terlengkap Tumbuh Kembang Anak Usia 0-5 Tahun. Surakarta: Cinta .

[6] Hasdianah, Siyoto, S., \& Nurwijayanti. (2017). Gizi, Pemanfaatan Gizi, Diet dan Obesitas. Yogyakarta: Nuha Medika.

[7] Hardinsyah \& Supariasa, D., (2017). IImu Gizi Teori \& Aplikasi. Jakarta: EGC.

[8] Indrayani, I., Rusmiadi, L. C., \& Kartikasari, A. (2020). Hubungan Antara Pengetahuan Dan Sikap Ibu Dengan Status Gizi Pada Balita Di Wilayah Uptd Puskesmas Cidahu Kecamatan Cidahu Kabupaten Kuningan. Jurnal Ilmu Kesehatan Bhakti Husada: Health Sciences Journal, 11(2), 224-234. https://doi.org/10.34305/jikbh.v11i2.199

[9] Kementrian kesesehatan Republik Indonesia (2019). Kemenkes Tingkat Status Gizi Masyarakat.

HYPERLINK

"https://www.kemkes.go.id/article/view/1981600004/kemenkes-tingkatkan-

status-gizi-masyarakat.html"

https://www.kemkes.go.id/article/view/1981600004/kemenkes-tingkatkan-

status-gizi-masyarakat.html

[10] Kementrian kesehatan Republik Indonesi (2020). Panduan Pelayanan Kseshatan Balita pada Masa Tanggap Darurat Covid-19 Bagi Tenaga Kesehatan. Jakarta: Kemenkes.

[11] Marzuki, I., \& Bachtiar, E.,et al. (2021). Covid-19 Seribu Satu Wajah. Jakarta:Yayasan Kita Menulis.

[12] Pakar Gizi Indonesia. (2016). IImu Gizi Teori \& Aplikasi. Jakarta: EGC.

[13] Proverawati, A., \& Asfuah, S. (2015). Buku Ajaran Gizi Untuk Kebidanan. Yogyakarta: Nuha Medika.

[14] Rokhanawati, D. (2020). Asuhan Neonatus Bayi, dan Balita. Yogyakarta: Nuha Medika.

[15] Safrizal,ZA \& Putra D.,et al. (2020). Pendoman Umum Menghadapi Pandemi Covid-19 Bagi Pemerintah Daerah Pencegahan, Pengendalian, Diagnosa, dan Menejemen. Jakarta: Tim Kerja Kemenkes.

[16] Salesiano, U. E. T., Fernández-Hernández, Ai., Educativos, S. D. E. F., 1234456487, Glosario, A. I., Posso, R., García Reyes, L. E., Autora, P., Pel, J., \& Espinoza, J. (2021). Gambaran Status Gizi Bayi dan Balita pada Masa Covid-19 Di Kalurahan Jetis Sukoharjo. Journal of Chemical Information and Modeling, 53(9), 6. 


\section{Prosiding Seminar Nasional Kesehatan $\mathbf{2 0 2 1}$ Lembaga Penelitian dan Pengabdian Masyarakat Universitas Muhammadiyah Pekajangan Pekalongan}

[17] Sari, M. G. K., Widyaningsih, V., Wardani, M. M., Murasmita, A., \& Ghufron, A. A. Hubungan Pemantauan Pertumbuhan Anak Baduta pada Masa Pandemi COVID19 dan Pengetahuan Ibu Tentang MP-ASI dengan Status Gizi. SEMAR (Jurnal IImu Pengetahuan, Teknologi, dan Seni bagi Masyarakat), 10(1), 70-77.

[18] Setyorini, C., \& Lieskusumastuti, A. D. (2021). Gambaran Status Gizi Bayi dan Balita pada Masa Covid-19 Di Kalurahan Jetis. Avicenna: Journal of Health Research, 4(1).

[19] Situasi Covid-19. 2021. HYPERLINK "https://www.kemkes.go.id/" https://www.kemkes.go.id/

[20] Sugihartono, A., \& Burhan et al. (2020). Pendoman Pencegahan dan Pengendalian Coronavirus Disease (Covid-19).Jakarta: Kementrian Kesehatan RI.

[21] Triwibowo, C., \& Pusphandani, M. E. (2017). Pengantar Dasar IImu Kesehatan Masyarakat. Yogyakarta: Nuha Medika.

[22] Unicef. (2020). Covid-19 dan Ana-anak di Indonesia. Jakarta: United Nation Children's Fund.

[23] Widowati, H., Mukhodim, S., \& Hanum, F. (2021). Faktor Predisposing , Enabling dan Reinforcing Penerapan Gizi Seimbang Pada Balita di Masa Pandemi di Sidoarjo. 027, 830-838.

[24] Winarsih. (2018). Pengantar Ilmu Gizi Dalam Kebidanan. Yogyakarta: Pusaka Baru Press. 